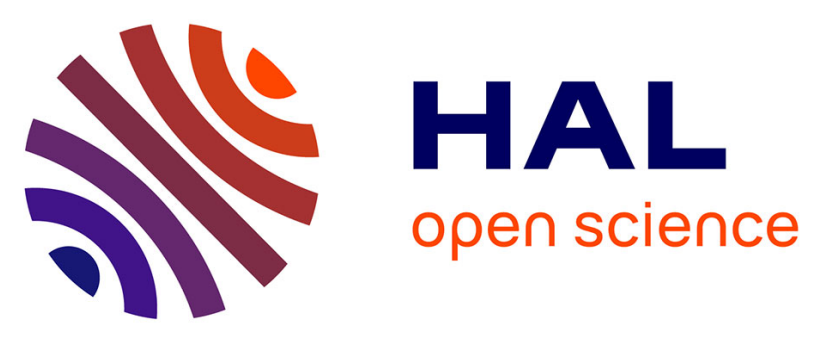

\title{
In vivo comparison between two nephrotoxic agents, sodium fluoride and uranyl nitrate: phenotypic aspects and molecular mechanisms involved
}

Alice Bontemps, Laurine Conquet, Christelle Elie, Victor Magneron, Celine Gloaguen, Dimitri Kereselidze, Karine Tack, Olivier Barbier, Yann Gueguen

\section{To cite this version:}

Alice Bontemps, Laurine Conquet, Christelle Elie, Victor Magneron, Celine Gloaguen, et al.. In vivo comparison between two nephrotoxic agents, sodium fluoride and uranyl nitrate: phenotypic aspects and molecular mechanisms involved. International Conference on the Health Effects of Incorporated Radionuclides, HEIR, Oct 2019, FONTENAY-AUX-ROSES, France. pp.05004, 10.1051/bioconf/20191405004 . hal-02635732

\section{HAL Id: hal-02635732 \\ https://hal.science/hal-02635732}

Submitted on 27 May 2020

HAL is a multi-disciplinary open access archive for the deposit and dissemination of scientific research documents, whether they are published or not. The documents may come from teaching and research institutions in France or abroad, or from public or private research centers.
L'archive ouverte pluridisciplinaire HAL, est destinée au dépôt et à la diffusion de documents scientifiques de niveau recherche, publiés ou non, émanant des établissements d'enseignement et de recherche français ou étrangers, des laboratoires publics ou privés.

$$
\text { Copyright }
$$




\title{
In vivo comparison between two nephrotoxic agents, sodium fluoride and uranyl nitrate: phenotypic aspects and molecular mechanisms involved
}

\author{
Alice Bontemps ${ }^{1,{ }^{*}, \text { Laurine Conquet }}{ }^{1}$, Christelle Elie ${ }^{1}$, Victor Magneron ${ }^{1}$, Céline \\ Gloaguen $^{1}$, Dimitri Kereselidze ${ }^{1}$, Karine Tack $^{1}$, Olivier Barbier ${ }^{2}$, and Yann Guéguen ${ }^{1}$ \\ ${ }^{1}$ Institut de Radioprotection et de Sûreté Nucléaire (IRSN), PRP-HOM, SESANE, LRTOX, 92262 \\ Fontenay-aux-Roses, France \\ ${ }^{2}$ Departamento de Toxicología, Centro de Investigación y de Estudios Avanzados del Instituto \\ Politécnico Nacional (CINVESTAV-IPN), Av. IPN No. 2508 Col, San Pedro Zacatenco, México \\ City, CP 07360, Mexico
}

\section{Background}

Humans can be exposed at low concentrations to toxic agents with anthropogenic and natural origins such as uranium and fluoride. Because of its functions of filtration, transport and reabsorption the kidney is a primary target organ of toxicity to foreign compounds. Uranium and fluoride are both known to be nephrotoxic, nevertheless there is a lack of knowledge of their mechanisms of nephrotoxicity and of the underlying molecular pathways involved $[1,2]$. This study aims to compare these agents to identify the cellular and molecular pathways of nephrotoxicity in mouse.

\section{Methods and results}

C57Bl6 mice are exposed to uranyl nitrate (UN) $(0,2,4,5 \mathrm{mg} / \mathrm{kg})$ or sodium fluoride (NaF) $(0,2,5,7.5,10 \mathrm{mg} / \mathrm{kg})$ by intraperitoneal injection and put into metabolism cages for 24 hours before and directly after injection. Collected urines are used to quantify uranium or fluoride, to measure specific and sensitive biomarkers of nephrotoxicity levels and to assess clinical bioassays. Finally, animals are euthanized $48 \mathrm{~h}$ and $72 \mathrm{~h}$ after exposure, chosen as the peak of nephrotoxicity is observed after intraperitoneal injection [3]. The protocol is shown in figure 1.

Renal phenotypic aspects and biological mechanisms are evaluated by urinary biochemistry, gene and protein expressions, enzyme activity, and histological analyses. Exposure to UN and $\mathrm{NaF}$ induces nephrotoxicity in a dose-dependent manner. A $5 \mathrm{mg} / \mathrm{kg}$ injection of UN induces mild histopathological alterations and respectively 44 and 6 -fold increase in gene expressions of nephrotoxicity markers KIM1 and osteopontin. In comparison, $10 \mathrm{mg} / \mathrm{kg}$ of $\mathrm{NaF}$ induces high nephrotoxicity with histopathological alterations scored as severe and late appearing parameters of toxicity whereas $7.5 \mathrm{mg} / \mathrm{kg}$

\footnotetext{
"Corresponding author: alice.bontemps(airsn.fr
} 


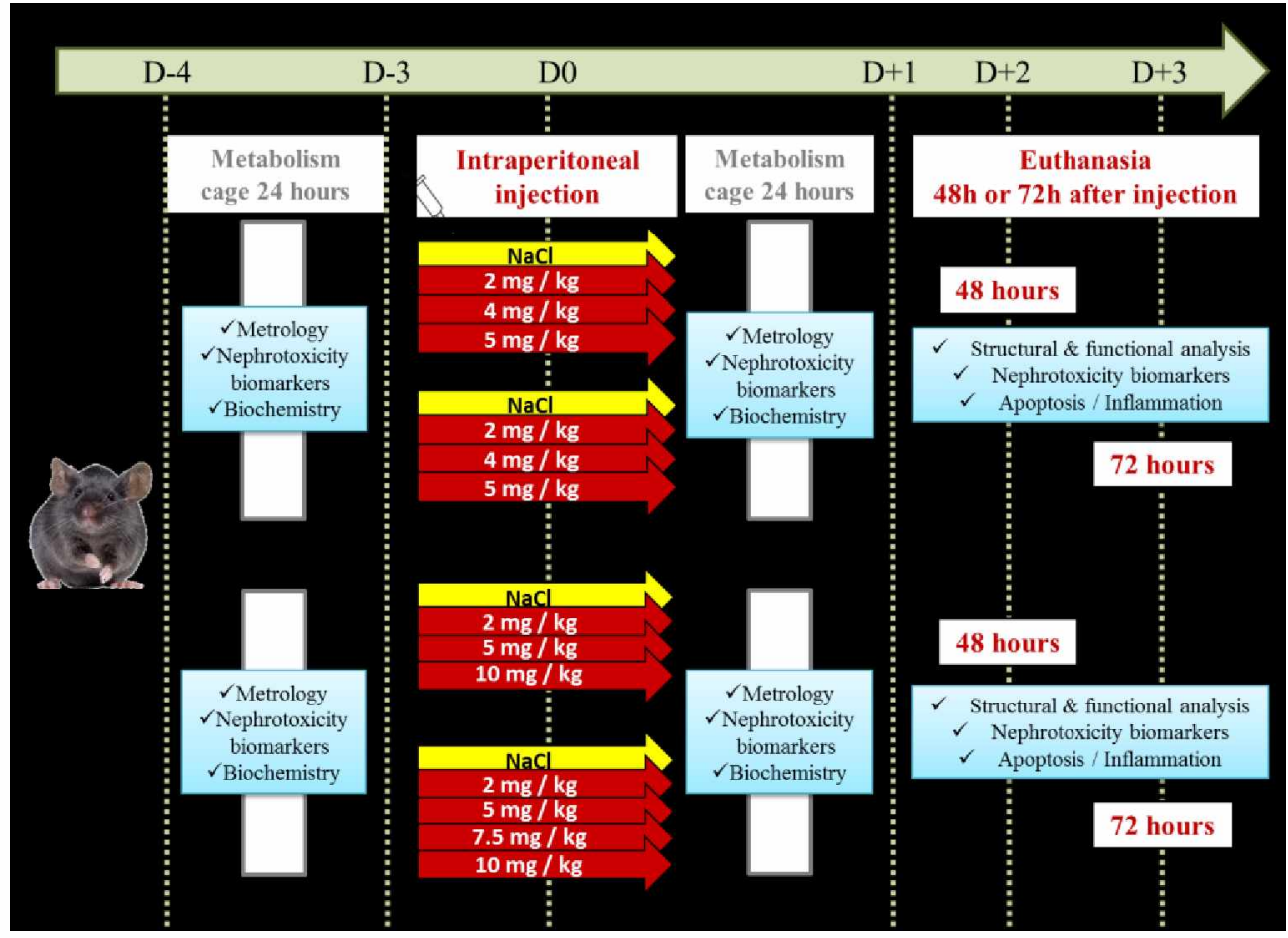

Fig. 1. Protocol of internal exposure of uranium and fluoride in mice C57B16. Scale of time is given at the top of the figure (in days). Day 4 before injection mice are put 24 hours in metabolism cages to collect urines, at day 0 mice are injected intraperitoneally with either uranium or fluoride and directly put in metabolism cages again. Day 2 or day 3 after injection mice are euthanized to extract kidneys.

induces mild histopathological scoring and gene expressions of KIM1 and clusterin enhanced respectively by 70 and 4 -fold compared to control. No signs of nephrotoxicity are observed below $5 \mathrm{mg} / \mathrm{kg}$ of NaF. Clusterin is respectively increased by 2.4 and 4.4 -fold in urines after 7.5 and $10 \mathrm{mg} / \mathrm{kg}$ injection of $\mathrm{NaF}$, whereas 4 and $5 \mathrm{mg} / \mathrm{kg}$ of UN induce respectively a 2.2 and 2.7-fold increase of clusterin in urines. Apoptosis is evaluated through caspases $3 / 7$ activity which is increased by $210 \%$ after UN treatment $(5 \mathrm{mg} / \mathrm{kg})$ whereas $\mathrm{NaF}$ does not induce apoptosis significantly. Inflammation is implied in UN and $\mathrm{NaF}$ acute nephrotoxicity as shown by gene and in situ overexpressions of ICAM and VCAM measurement by immunohistochemical staining.

\section{Conclusions}

$\mathrm{UN}$ and $\mathrm{NaF}$ acute exposures resulted in dose and time-dependent nephrotoxicity with a higher nephrotoxicity after $72 \mathrm{~h}$. Inflammation and apoptosis are both involved in UN or $\mathrm{NaF}$ toxicity. These observations allow us to identify the mechanisms that will be studied in a low-dose exposure protocol after a chronic exposure.

\section{References}

1. Y. Gueguen, \& C. Rouas, Radioprotection, 47(3), 345-359 (2012)

2. O. Barbier, L. Arreola-Mendoza, et al., Chem Biol Interact 188(2): 319-333 (2010)

3. P. Sangeetha Vijayan, P. D. Rekha, et al., Ren Fail 38(5): $770-775$ (2016) 